\section{RSP}

http://www.rsp.fsp.usp.br/
Revista de Saúde Pública

\title{
Most-cited public health articles of scientific journals from Brazil
}

\author{
Milena Maria de Araújo Lima Barbosa' iD, Angela Maria Belloni Cuenca" iD, Karoline \\ de Oliveira"' iD, Ivan França Junior"I iD, Maria do Carmo Avamilano Alvarez ${ }^{\text {Iv }}$ iD, Larissa \\ Yuko Omae ${ }^{\mathrm{v}}$ iD \\ I Universidade de São Paulo. Faculdade de Saúde Pública. Programa de Pós-Graduação em Saúde Pública. São \\ Paulo, SP, Brasil \\ " Universidade de São Paulo. Faculdade de Saúde Pública. Departamento de Saúde, Ciclos de Vida e Sociedade. \\ São Paulo, SP, Brasil \\ II' Universidade de São Paulo. Faculdade de Saúde Pública. Programa Institucional de Bolsas de Iniciação \\ Científica. São Paulo, SP, Brasil \\ Iv Universidade de São Paulo. Faculdade de Saúde Pública. Biblioteca: Centro de Informação e Referência. São \\ Paulo, SP, Brasil \\ $\checkmark$ Universidade de São Paulo. Faculdade de Saúde Pública. Programa Unificado de Bolsas. São Paulo, SP, Brasil
}

Correspondence:

Milena Maria de Araújo Lima Barbosa

Faculdade de Saúde Pública

Av. Dr. Arnaldo, 715

01246-904 São Paulo, SP, Brasil

E-mail: milenaaraujo@usp.br

Received: 1 mar 2019

Approved: 15 abr 2019

How to cite: Barbosa MMAL, Cuenca AMB, Oliveira K, França Junior I, Alvarez MCA, Omae LY. Most-cited public health articles of scientific journals from Brazil. Rev Saude Publica. 2019;53:81.

Copyright: This is an open-access article distributed under the terms of the Creative Commons Attribution License, which permits unrestricted use, distribution, and reproduction in any medium, provided that the original author and source are credited.

\section{ABSTRACT}

OBJECTIVE: To describe the most-cited articles in public health scientific journals edited in Brazil.

METHODS: Articles published between 2008 and 2010 by public health journals edited in Brazil and indexed in the Scopus database were included, and citations received up to five years after publication were ranked. We studied a total of 105 articles, as the last seven articles shared the same number of citations and so were given the same rank.

RESULTS: The most-cited articles received a median of 28 citations, and the distribution ranged from 22 to 95 citations. These articles describe advances in the areas of Epidemiology (74\%), Health Policies, Planning and Administration (19\%), and Social and Human Sciences in Health (7\%). Only half mentioned that they have received funding. About $75 \%$ of the articles were written by three or more authors and $90 \%$, by authors affiliated to public institutions such as universities and government organizations. Fifteen individuals were responsible for authoring or coauthoring three or more of the 105 articles studied. The journals Cadernos de Saúde Pública, Revista de Saúde Pública, and Ciência \& Saúde Coletiva have published the vast majority of the most-cited articles in the area (94\%).

CONCLUSIONS: In Brazil, the most-cited articles in public health mainly report Epidemiology research, are written by groups of authors and by researchers affiliated to public institutions and are published in journals with a greater impact. Periodical analyses of these data can show potential changes in the characteristics of articles that most attract public health scientists.

DESCRIPTORS: Periodicals as Topic. Citation Databases. Public Health. Bibliometrics. 


\section{INTRODUCTION}

Citations are considered an indirect measurement of the contribution of an article to the knowledge generated in the field, i.e., the link between the finding of the investigation and its importance for science ${ }^{1}$. Therefore, citations have been widely used and valued to provide indices and impact indicators in science ${ }^{2}$. Garfield and Welljams-Dorof ${ }^{3}$ have identified a significant correlation between the quality and relevance of an article and the number of citations it receives.

By analyzing articles that exert the greatest influence on a field of knowledge, we identified where, how, and by which scientists this field moves forward. Thus, several studies have evaluated highly-cited articles in specific fields such as Rheumatology ${ }^{4}$, Gastroenterology ${ }^{5}$, Psychiatry $^{6}$, Surgery ${ }^{7}$, among others. The most-cited articles represent a high degree of research impact and an effective investment of resources ${ }^{8}$.

Public health is a field of production of multi- and interdisciplinary scientific knowledge ${ }^{9}$, based on epidemiology, social and human sciences in health, and policies, planning and administration in health ${ }^{10}$. This field provides an excellent opportunity to evaluate citation performance among areas. Smith and Leggat ${ }^{11}$ evaluated the 10 most-cited articles in public health, but the authors included articles from only one journal.

In Brazil, few studies have addressed the question of citations, and they are usually from the areas of Information Science, Bibliometrics, and Scientometrics ${ }^{12-14}$. In specific fields such as public health, some authors, such as Coimbra $\mathrm{Jr}^{15}$, Barata ${ }^{16}$, Iriart et al. ${ }^{10}$, Cuenca et al. ${ }^{17}$, have been analyzing the citations attributed to journals and articles, but few of them address the most-cited ones.

This study aimed to characterize the most-cited articles published in public health journals edited in Brazil. Our findings should help students, young researchers, and readers in general to become familiar with the authors, institutions, and journals that have made a leading contribution to public health in Brazil. Also, this study may provide researchers, research funding agencies, and university administrators with insights into the research trends in this field.

\section{METHODS}

Following the trend of bibliometric studies considering the so-called "top 100" of an area of knowledge, we present here the most-cited articles published in Brazilian public health journals.

To assess those articles, we selected the public health scientific journals that are edited in Brazil, according to the Associação Brasileira de Saúde Coletiva (Abrasco - Brazilian Association of Collective Health), which have been indexed in the Scopus database since 2008. This database was chosen because, besides being one of the main sources of bibliometric data, it indexes more journals edited in Brazil. The initial year was chosen to increase the number of journals represented since fewer journals were edited in Brazil on this database until 2007. Thus, the following journals were selected: Cadernos de Saúde Pública; Ciência \& Saúde Coletiva; História, Ciências, Saúde - Manguinhos; Interface: Communicação, Saúde, Educação; Physis; Revista Brasileira de Epidemiologia; Revista de Saúde Pública; and Saúde \& Sociedade.

For the retrieval of the articles, we searched for records classified by Scopus as original articles or review articles, published between 2008 and 2010. The final year was considered to include citations received up to five years after publication since citations usually do not occur soon after publication. So, for articles published in 2008 , we studied citations received until 2013, and so on. This standardization provides, for all articles, the same time availability to receive citations. Initially, we retrieved 3,242 records and, after the age 
adjustment, we filtered those articles in descending order of citations and selected the 100 most-cited ones. However, seven papers ranked last in the classification, as they contained the same number of citations (22 citations). Overall, in this study, we included the 105 most cited articles.

We performed the descriptive analysis of the articles included according to the following variables: citation ranking, publication year, publication language, publication type, thematic category, journal title, number of authors (one, two, three, or more), authors' names, and funding. The type of publication was classified into two stages: first, we evaluated whether the article was methodological or not; second, if it was not methodological, we evaluated whether it was an original study or a review. The thematic addressed in the articles was based on the categories defined by Abrasco for the area of Collective Health, namely: epidemiology; policies, planning, and administration in health; and social and human sciences in health. The first author's affiliation was classified as a public university, private university, hospital, governmental institution, or non-governmental institution. The funding institutions were categorized into: development agency, such as Research Support Foundations (FAP) and Brazilian National Council for Scientific and Technological Development (CNPq); national governing bodies, such as ministries and state departments; foreign or national institutions, such as World Health Organization; and scientific associations or societies.

\section{RESULTS}

Among the 3,242 articles published between 2008 and 2010 by the journals included in this study, the most-cited articles $(\mathrm{n}=105)$ received between 22 and 95 citations, with a median of 28 (p25 = 24 and p75 = 36). The 105 most-cited articles are listed in the Table 1 .

As described in Table 2, of the 105 articles, most were original articles (70\%), in the area of Epidemiology (74\%), written by three or more authors (74\%) and published in English (57\%). All have abstracts in Portuguese and English, and 34 (32\%) also have an Abstract in Spanish. It is worth noting that, despite standardizing the citation window (citations up to five years after publication), we identified a few of the most-cited articles published in 2010.

Cadernos de Saúde Pública, Revista de Saúde Pública, and Ciência \& Saúde Coletiva have published the vast majority of the most-cited articles in the area (94\%). Another group is constituted by the Revista Brasileira de Epidemiologia, Interface, História, Ciência \& Saúde, Physis, and Saúde e Sociedade, the articles in which seldom if ever feature among the most-cited ones. The distribution of the most-cited articles according to the journal is shown in Table 3.

Regarding the affiliations of the first author of each article (Table 4), public universities represented $67 \%$ of the institutions. Authors were also affiliated to governmental organizations (23\%) - such as the Fiocruz Foundation, the Ministry of Health and health departments - and to private undergraduate institutions (6\%).

Regarding research funding, 52 articles reported some kind of funding; of these, half reported support from two or more institutions. The most frequently mentioned funding agencies or institutions were FAP (35/52) and CNPq (31/52). Support from foreign agencies was mentioned in 25 of the 52 articles (48\%). Brazilian government agencies accounted for $21 \%(11 / 52)$ of these grants, and a research incentive association accounted for 1 grant (data not shown in table).

In relation to authorship and coauthorship, in total, 388 individuals were responsible for authoring or coauthoring these articles. Table 5 shows the most-productive researchers $(\mathrm{n}=15)$. In addition, eight other researchers were responsible for 1 authorship and 1 coauthorship; 26, for two coauthorships; 84, for 1 authorship; and 255, for 1 coauthorship (data not shown in table). 
Table 1. The most-cited articles of public health scientific journals edited in Brazil.

Rank Reference

Veras R. Population aging today: Demands, challenges and innovations. Rev Saúde Pública. 2009; 43(3):548-54. http://dx.doi. org/10.1590/S0034-89102009005000025

Fontanella BJB, Ricas J, Turato ER. Saturation sampling in qualitative health research: Theoretical contributions. Cad Saúde Pública. 2008; 24(1):17-27. http://dx.doi.org/10.1590/S0102-311X2008000100003

Monteiro CA, Benicio MHD'A, Konno SC, Silva ACF, Lima ALL, Conde WL. Causes for the decline in child under-nutrition in Brazil 1996-2007. Rev Saúde Pública. 2009; 43(1):35-43. http://dx.doi.org/10.1590/S0034-89102009000100005

Teixeira MG, Costa MCN, Barreto F, Barreto ML. Dengue: Twenty-five years since reemergence in Brazil. Cad Saúde Pública. 2009;

$4 \quad 25(1): S 7-S 18$.

http://dx.doi.org/10.1590/S0102-311X2009001300002

Moura EC, Neto OLM, Malta DC, Moura L, Silva NN, Bernal R, et al. Surveillance of risk-factors for chronic diseases through

5 telephone interviews in 27 Brazilian cities (2006). Rev Bras Epidemiol. 2008; 11(1):20-37. http://dx.doi.org/10.1590/S1415$790 \times 2008000500003$

Ooi E, Gubler DJ. Dengue in Southeast Asia: Epidemiological characteristics and strategic challenges in disease prevention. Cad Saúde Pública. 2008; 25(1):S115-S124. http://dx.doi.org/10.1590/S0102-311X2009001300011

Coutinho LMS, Scazufca M, Menezes PR. Methods for estimating prevalence ratios in cross-sectional studies. Rev Saúde Pública. 2008; 42(6):992-8. http://dx.doi.org/10.1590/S0034-89102008000600003

Florindo AA, Hallal PC, Moura EC, Malta DC. Practice of physical activities and associated factors in adults, Brazil, 2006. Rev Saúde Pública. 2009; 43(2):65-73. http://dx.doi.org/10.1590/S0034-89102009000900009

Monteiro CA, Levy RB, Claro RM, Castro IRR, Cannon G. A new classification of foods based on the extent and purpose of their processing. Cad Saúde Pública. 2010; 26(11):2039-2049. http://dx.doi.org/10.1590/S0102-311X2010001100005

Maia-Elkhoury ANS, Alves WA, Sousa-Gomes ML, Sena JM, Luna EA. Visceral leishmaniasis in Brazil: Trends and challenges. Cad Saúde Pública. 2008; 24(12):2941-2947. http://dx.doi.org/10.1590/S0102-311X2008001200024

Passos CJS, Mergler D. Human mercury exposure and adverse health effects in the Amazon: A review. Cad Saúde Pública. 2008;

11 24(4):S503-S520

http://dx.doi.org/10.1590/S0102-311X2008001600004

12 Gigante DP, Moura EC, Sardinha LMV. Prevalence of overweight and obesity and associated factors, Brazil, 2006. Rev Saúde Pública 2009; 43(2):83-9. http://dx.doi.org/10.1590/S0034-89102009000900011

Diniz D, Medeiros M. Abortion in Brazil: A household survey using the ballot box technique. Cien Saúde Colet. 2010; 15(1):959-966. http://dx.doi.org/10.1590/S1413-81232010000700002

Benedetti TRB, Borges LJ, Petroski EL, Gonçalves LHT. Physical activity and mental health status among elderly people. Rev Saúde Pública. 2008; 42(2):302-7. http://dx.doi.org/10.1590/S0034-89102008005000007

Alves E, Vasconcelos FAG, Calvo MCM, Neves J. Prevalence of symptoms of anorexia nervosa and dissatisfaction with body image

15 among female adolescents in Florian $\tilde{A}^{3}$ polis, Santa Catarina State, Brazil . Cad Saúde Pública. 2008; 24(3):503-512. http://dx.doi. org/10.1590/S0102-311X2008000300004

Giovanella L, Mendonça MHM, Almeida PF, Escorel S, Senna MCM, Fausto MCR, et al. Family health: Limits and possibilities

16 for an integral primary healthcare approach in Brazil. Cien Saúde Colet. 2009; 14(3):783-794. http://dx.doi.org/10.1590/S141381232009000300014

17 Sarno F, Claro RM, Levy RB, Bandoni DH, Ferreira SRG, Monteiro CA. Estimated sodium intake by the Brazilian population, 20022003. Rev Saúde Pública. 2009; 43(2):219-25. http://dx.doi.org/10.1590/S0034-89102009005000002

18 Mendes EV. Health care networks. Cien Saúde Colet. 2010; 15(5):2297-2305. http://dx.doi.org/10.1590/S1413-81232010000500005

Alfradique ME, Bonolo PF, Dourado I, Lima-Costa MF, Macinko J, Mendonça CS, et al. Ambulatory care sensitive hospitalizations:

19 Elaboration of brazilian list as a tool for measuring health system performance (project ICSAP - Brazil). Cad Saúde Publica. 2009; 25(6):1337-1349. http://dx.doi.org/10.1590/S0102-311X2009000600016

Malta DC, Sardinha LMV, Mendes I, Maria Barreto S, Giatti L, Castro IRR, et al. Prevalence of risk health behavior among adolescents:

20 Results from the 2009 national adolescent school-based health survey (PeNSE). Cien Saúde Colet. 2010; 15(2):3009-3019. http://dx.doi. org/10.1590/S1413-81232010000800002

21 Silveira MF, Santos IS, Barros AJD, Matijasevich A, Barros FC, Victora CG. Increase in preterm births in Brazil: Review of populationbased studies. Rev Saúde Pública. 2008; 42(5):957-64. http://dx.doi.org/10.1590/S0034-89102008000500023

Conill EM. A historical and conceptual model for Primary Health Care: Challenges for the organization of primary care and

22 the Family Health Strategy in large Brazilian cities. Cad Saúde Pública. 2008; 24(1):S7-S27. http://dx.doi.org/10.1590/S0102$311 \times 2008001300002$

Duailibi LB, Ribeiro M, Laranjeira R. Profile of cocaine and crack users in Brazil. Cad Saúde Pública. 2008; 24(4):S545-S557. http:// dx.doi.org/10.1590/S0102-311X2008001600007

Ribeiro AQ, Rozenfeld S, Klein CH, Cesar CC, Acurcio FA. Survey on medicine use by elderly retirees in Belo Horizonte,

24 Southeastern Brazil. Rev Saúde Pública. 2008; 42(4):724-32. http://dx.doi.org/10.1590/S0034-89102008005000031

Chieffi AL, Barata RB. "Judicialization" of public health policy for distribution of medicines. Cad Saúde Pública. 2009; 25(8):18391849. http://dx.doi.org/10.1590/S0102-311X2009000800020

Fernandes LCL, Bertoldi AD, Barros AJD. Health service use in a population covered by the Estrat $\tilde{A} \odot$ gia de SaÃ de da Fam $\tilde{A} l i a(F a m i l y$ Health Strategy). Rev Saúde Pública. 2009; 43(4):595-603. http://dx.doi.org/10.1590/S0034-89102009005000040 
Table 1. The most-cited articles of public health scientific journals edited in Brazil. Continuation

Couto MT, Pinheiro TF, Valença O, Machin R, Silva GSN, Gomes R, et al. Men in primary healthcare: Discussing (in) visibility

27 based on gender perspectives. Interface - Comunic., Saúde, Educ.. 2010; 14(33):257-70. http://dx.doi.org/10.1590/S141432832010000200003

Siqueira FV, Facchini LA, Piccini RX, Tomasi E, Thumé E, Silveira DS, et al. Physical activity in young adults and the elderly in areas covered

28 by primary health care units in municipalities in the South and Northeast of Brazil. Cad Saúde Pública. 2008; 24(1):39-54. http://dx.doi. org/10.1590/S0102-311X2008000100005

Levy RB, Castro IRR, Cardoso LO, Tavares LF, Sardinha LMV, Gomes FS, et al. Food consumption and eating behavior among brazilian

29 adolescents: National adolescent school-based health survey (PeNSE), 2009. Cien Saúde Colet. 2010; 15(2):3085-3097. http://dx.doi. org/10.1590/S1413-81232010000800013

30 Carvalho JAM, Rodríguez-Wong LL. The changing age distribution of the Brazilian population in the first half of the 21 st century. Cad Saúde Pública. 2008; 24(3):597-605. http://dx.doi.org/10.1590/S0102-311X2008000300013

31 Salvador EP, Florindo AA, Reis RS, Costa EF. Perception of the environment and leisure-time physical activity in the elderly. Rev Saúde Pública. 2009; 43(6):972-80. http://dx.doi.org/10.1590/S0034-89102009005000082

Seabra AF, Mendonça DM, Thomis MA, Anjos LA, Maia JA. Biological and socio-cultural determinants of physical activity in adolescents. Cad Saúde Pública. 2008; 24(4):721-736. http://dx.doi.org/10.1590/S0102-311X2008000400002

Barros FC, Victora CG, Scherpbier R, Gwatkin D. Socioeconomic inequities in the health and nutrition of children in low/middle income countries. Rev Saúde Pública. 2010; 44(1):1-16. http://dx.doi.org/10.1590/S0034-89102010000100001

Souza ECF, Vilar RLA, Rocha NSPD, Uchoa AC, Rocha PM. Primary health care access and receptivity to users: An analysis of

34 perceptions by users and health professionals. Cad Saúde Pública. 2008; 24(1):S100-S110. http://dx.doi.org/10.1590/S0102311 X2008001300015

35 Enes CC, Slater B. Obesity in adolescence and its main determinants. Rev Bras Epidemiol. 2010; 13(1):163-71. http://dx.doi. org/10.1590/S1415-790X2010000100015

36 Malta M, Cardoso LO, Bastos FI, Magnanini MMF, Silva CMFP. STROBE initiative: guidelines on reporting observational studies. Rev Saúde Pública. 2010; 44(3):559-65. http://dx.doi.org/10.1590/S0034-89102010000300021

Carret MLV, Fassa ACG, Domingues MR. Inappropriate use of emergency services: A systematic review of prevalence and associated factors. Cad Saúde Pública. 2009; 25(1):7-28. http://dx.doi.org/10.1590/S0102-311X2009000100002

38 Coutinho JG, Gentil PC, Toral N. Malnutrition and obesity in Brazil: Dealing with the problem through a unified nutritional agenda. Cad Saúde Pública. 2008; 24(2):S332-S340. http://dx.doi.org/10.1590/S0102-311X2008001400018

39 Schlussel MM, Souza EB, Reichenheim ME, Kac G. Physical activity during pregnancy and maternal-child health outcomes: A
systematic literature review. Cad Saúde Pública. 2008; 24(4):S531-S544. http://dx.doi.org/10.1590/S0102-311X2008001600006

Sousa MF, Hamann EM. Family health program in brazil: An incomplete agenda?. Cien Saúde Colet. 2009; 14(1):1325-1335. http:// dx.doi.org/10.1590/S1413-81232009000800002

Lagrotta MTF, Silva WC, Souza-Santos R. Identification of key areas for Aedes aegypti control through geoprocessing in Nova

41 IguaÃßu, Rio de Janeiro State, Brazil. Cad Saúde Pública. 2008; 24(1):70-80. http://dx.doi.org/10.1590/S0102-311X2008000100007

Moura FBP, Marques JGW. Folk medicine using animals in the Chapada Diamantina: Incidental medicine?. Cien Saúde Colet. 2008; 13(2):2179-2188. http://dx.doi.org/10.1590/S1413-81232008000900023

Tesch FC, Oliveira BH, Leão A. Semantic equivalence of the Brazilian version of the Early Childhood Oral Health Impact Scale. Cad Saúde Pública. 2008; 24(8):1897-1909. http://dx.doi.org/10.1590/S0102-311X2008000800018

Szwarcwald CL, Damacena GN. Complex Sampling Design in Population Surveys: Planning and effects on statistical data analysis. Rev Bras Epidemiol. 2008; 11(1):38-45. http://dx.doi.org/10.1590/S1415-790X2008000500004

Jaime PC, Figueiredo ICR, Moura EC, Malta DC. Factors associated with fruit and vegetable consumption in Brazil, 2006. Rev Saúde Pública. 2009; 43(2):57-64. http://dx.doi.org/10.1590/S0034-89102009000900008

46 Vieira FS. Ministry of health's spending on drugs: Program trends from 2002 to 2007. Rev Saúde Pública. 2009; 43(4):674-81. http:// dx.doi.org/10.1590/S0034-89102009005000041

Silva Alexandre T, Cordeiro RC, Ramos LR. Factors associated to quality of life in active elderly. Rev Saúde Pública. 2009; 43(4):61321. http://dx.doi.org/10.1590/S0034-89102009005000030

Bernal R, Silva NN. Home landline telephone coverage and potential bias in epidemiological surveys. Rev Saúde Pública. 2009;

$48 \quad 43(3): 421-6$.

http://dx.doi.org/10.1590/S0034-89102009005000024

Gonçalves DM, Stein AT, Kapczinski F. Performance of the Self-Reporting Questionnaire as a psychiatric screening questionnaire:

49 A comparativestudy with Structured Clinical Interview for DSM-IV-TR. Cad Saúde Pública. 2008; 24(2):380-390. http://dx.doi. org/10.1590/S0102-311X2008000200017

Paiva V, Calazans G, Venturi G, Dias R. Age and condom use at first sexual intercourse of Brazilian adolescents. Rev Saúde Pública. 2008; 42(1):45-53. http://dx.doi.org/10.1590/S0034-89102008000800007

Pinter A, Horta MC, Pacheco RC, Moraes-Filho J, Labruna MB. Serosurvey of Rickettsia spp. in dogs and humans from an endemic

51 area for Brazilian spotted fever in the State of SÃ £o Paulo, Brazil. Cad Saúde Pública. 2008; 24(2):247-252. http://dx.doi.org/10.1590/ S0102-311X2008000200003

Barros FC, Victora CG, Matijasevich A, Santos IS, Horta BL, Silveira MF, et al. Preterm births, low birth weight, and intrauterine

52 growth restriction in three birth cohorts in Southern Brazil: 1982, 1993 and 2004. Cad Saúde Pública. 2008; 24(3):S390-S398. http:// dx.doi.org/10.1590/S0102-311X2008001500004

Silveira VMF, Horta BL. Birth weight and metabolic syndrome in adults: Meta-analysis. Rev Saúde Pública. 2008; 42(1):10-8. http:// dx.doi.org/10.1590/S0034-89102008000100002 
Table 1. The most-cited articles of public health scientific journals edited in Brazil. Continuation

54 Martins AMEBM, Barreto SM, Pordeus IA. Objective and subjective factors related to self-rated oral health among the elderly. Cad

54 Saúde Pública. 2009; 25(2):421-435. http://dx.doi.org/10.1590/S0102-311X2009000200021

55 Camargo MBJ, Dumith SC, Barros AJD. Regular use of dental care services by adults: Patterns of utilization and types of services. Cad Saúde Pública. 2009; 25(9):1894-1906. http://dx.doi.org/10.1590/S0102-311X2009000900004

56 Menezes G, Aquino EML. Research on abortion in Brazil: Gaps and challenges for the public health field. Cad Saúde Pública. 2009; 25(2):S193-S204. http://dx.doi.org/10.1590/S0102-311X2009001400002

57 Schraiber LB, Figueiredo WS, Gomes R, Couto MT, Pinheiro TF, Machin R, et al. Health needs and masculinities: Primary health care services for men. Cad Saúde Pública. 2010; 26(5):961-970. http://dx.doi.org/10.1590/S0102-311X2010000500018

Araújo CL, Menezes AMB, Vieira MFA, Neutzling MB, Gonçalves H, Anselmi L, et al. The 11-year follow-up of the 1993

58 Pelotas (Brazil) birth cohort study: Methods. Cad Saúde Pública. 2010; 26(10):1875-1886. http://dx.doi.org/10.1590/S0102$311 \times 2010001000003$

59 Lino VTS, Pereira SRM, Camacho LAB, Ribeiro Filho ST, Buksman S. Cross-cultural adaptation of the Independence in Activities of Daily Living Index (Katz Index). Cad Saúde Pública. 2008; 24(1):103-112. http://dx.doi.org/10.1590/S0102-311X2008000100010

Castro IRR, Cardoso LO, Engstrom EM, Levy RB, Monteiro CA. Surveillance of risk factors for non-communicable diseases among

60 adolescents: The experience in Rio de Janeiro, Brazil. Cad Saúde Pública. 2008; 24(10):2279-2288. http://dx.doi.org/10.1590/S0102$311 \times 2008001000009$

61 Costa $\mathrm{CHN}$. Characterization and speculations on the urbanization of visceral leishmaniasis in Brazil. Cad Saúde Pública. 2008; 24(12):2959-2963. http://dx.doi.org/10.1590/S0102-311X2008001200027

Figueiredo MD, Campos RO. Mental health in the primary care system of Campinas, SP: Network or spider's web?. Cien Saúde Colet. 2009; 14(1):129-138. http://dx.doi.org/10.1590/S1413-81232009000100018

Batista Filho M, Souza Al, Miglioli TC, Santos MC. Anemia and obesity: A paradox of the nutritional transition in Brazil. Cad Saúde Pública. 2008; 24(2):S247-S257. http://dx.doi.org/10.1590/S0102-311X2008001400010

Barros FC, Victora CG, Horta BL, Gigante DP. Methodology of the Pelotas birth cohort study from 1982 to 2004-5, Southern Brazil. Rev Saúde Pública. 2008; 42(2):7-15. http://dx.doi.org/10.1590/S0034-89102008000900003

Strauch ES, Pinheiro RT, Silva RA, Horta BL. Alcohol use among adolescents: A population-based study. Rev Saúde Pública. 2009; 43(4):647-55. http://dx.doi.org/10.1590/S0034-89102009005000044

66 Oliveira LG, Nappo SA. Characterization of the crack cocaine culture in the city of SÃ £o Paulo: A controlled pattern of use. Rev Saúde Pública. 2008; 42(4):664-71. http://dx.doi.org/10.1590/S0034-89102008005000039

Oliveira LPM, Assis AMO, Silva MCM, Santana MLP, Santos NS, Pinheiro SMC, et al. Factors associated with overweight and

67 abdominal fat in adults in Salvador, Bahia State, Brazil. Cad Saúde Pública. 2009; 25(3):570-582. http://dx.doi.org/10.1590/S0102 311 X2009000300012

Albuquerque KM, Frias PG, Andrade CLT, Aquino EML, Menezes G, Szwarcwald CL. Pap smear coverage and factors associated with non-participation in cervical cancer screening: An analysis of the Cervical Cancer Prevention Program in Pernambuco State, Brazil. Cad Saúde Pública. 2009; 25(2):S301-309. http://dx.doi.org/10.1590/S0102-311X2009001400012

Malta DC, Silva MAI, Mello FCM, Monteiro RA, Sardinha LMV, Crespo C, et al. Bullying in Brazilian schools: Results from the

69 national school-based health survey (PeNSE), 2009. Cien Saúde Colet. 2010; 15(2):3065-3076. http://dx.doi.org/10.1590/S141381232010000800011

70 Tenório MCM, Barros MVG, Tassitano RM, Bezerra J, Tenório JM, Hallal PC. Physical activity and sedentary behavior among adolescent high school students. Rev Bras Epidemiol. 2010; 13(1):105-17. http://dx.doi.org/10.1590/S1415-790X2010000100010

Schraiber LB, Latorre MRDO, França Jr I, Segri NJ, Lucas D'Oliveira AFP. Validity of the WHO VAW study instrument for

71 estimating gender-based violence against women. Rev Saúde Pública. 2010; 44(4):658-66. http://dx.doi.org/10.1590/S003489102010000400009

72 Rangel EF, Vilela ML. Lutzomyia longipalpis (Diptera, Psychodidae, Phlebotominae) and urbanization of visceral leishmaniasis in Brazil. Cad Saúde Pública. 2008; 24(12):2948-2952. http://dx.doi.org/10.1590/S0102-311X2008001200025

Santos AMR, Moura MEB, Nunes BMVT, Leal CFS, Teles JBM. Profile of motorcycle accident victims treated at a public hospital emergency department. Cad Saúde Pública. 2008; 24(8):1927-1938. http://dx.doi.org/10.1590/S0102-311X2008000800021

Louvison MCP, Lebrão ML, Duarte YAO, Santos JLF, Malik AM, Almeida ES. Inequalities in access to health care services

74 and utilization for the elderly in Sao Paulo, Brazil. Rev Saúde Pública. 2008; 42(4):733-40. http://dx.doi.org/10.1590/S003489102008000400021

75 Lima CRA, Schramm JMA, Coeli CM, Silva MEM. Review of data quality dimensions and applied methods in the evaluation of health information systems. Cad Saúde Pública. 2009; 25(10):2095-2109. http://dx.doi.org/10.1590/S0102-311X2009001000002

Munayco CV, Grijalva CG, Culqui DR, Bolarte JL, Suarez-Ognio LA, Quispe N, et al. Outbreak of persistent cutaneous abscesses due

76 to Mycobacterium chelonae after mesotherapy sessions, Lima, Peru. Rev Saúde Pública. 2008; 42(1):146-9. http://dx.doi.org/10.1590/ S0034-89102008000100020

Schmidt MI, Duncan BB, Hoffmann JF, Moura L, Malta DC, Carvalho RMSV. Prevalence of diabetes and hypertension based

77 on selfreported morbidity survey, Brazil, 2006. Rev Saúde Pública. 2009; 43(2):74-82. http://dx.doi.org/10.1590/S003489102009000900010

78 Moraes ACF, Fulaz CS, Netto-Oliveira ER, Reichert FF. Prevalence of metabolic syndrome in adolescents: A systematic review. Cad Saúde Pública. 2009; 25(6):1195-1202. http://dx.doi.org/10.1590/S0102-311X2009000600002

Gonçalves CV, Cesar JA, Mendoza-Sassi RA. Quality and equity in prenatal care: A population-based study in southern Brazil. Cad Saúde Pública. 2009; 25(11):2507-2516. http://dx.doi.org/10.1590/S0102-311X2009001100020 
Table 1. The most-cited articles of public health scientific journals edited in Brazil. Continuation

80 Araújo CS, Lima RC, Peres MA, Barros AJD. Use of dental services and associated factors: A population-based study in southern Brazil. Cad Saúde Pública. 2009; 25(5):1063-1072. http://dx.doi.org/10.1590/S0102-311X2009000500013

Castro HA, Cunha MF, Mendonça GAS, Junger WL, Cunha-Cruz J, Leon AP. Effect of air pollution on lung function in schoolchildren in Rio de Janeiro, Brazil. Rev Saúde Pública. 2009; 43(1):26-34. http://dx.doi.org/10.1590/S0034-89102009000100004

Lima LHM, Viana MC. Prevalence and risk factors for HIV, syphilis, hepatitis B, hepatitis C, and HTLV-I/II infection in low-income

82 postpartum and pregnant women in Greater Metropolitan Vit ̃³ria, EspÃrito Santo State, Brazil. Cad Saúde Pública. 2009; 25(3):668676. http://dx.doi.org/10.1590/S0102-311X2009000300021

Ignotti E, Valente JG, Longo KM, Freitas SR, Hacon SS, Netto PA. Impact on human health of particulate matter emitted from burnings in the Brazilian Amazon region. Rev Saúde Pública. 2010; 44(1):121-30. http://dx.doi.org/10.1590/S0034-89102010000100013

Mitre SM, Siqueira-Batista R, Girardi-de-Mendonça JM, Morais-Pinto NM, Meirelles CAB, Pinto-Porto C, et al. Active teaching-

Giacomin KC, Peixoto SV, Uchoa E, Lima-Costa MF. A population-based study on factors associated with functional disability among older adults in the Great Metropolitan Belo Horizonte, Minas Gerais State, Brazil. Cad Saúde Pública. 2008; 24(6):1260-1270. http:// dx.doi.org/10.1590/S0102-311X2008000600007

Paniz VMV, Fassa AG, Facchini LA, Bertoldi AD, Piccini RX, Tomasi E, et al. Access to continuous-use medication among adults and the elderly in South and Northeast Brazil. Cad Saúde Pública. 2008; 24(2):267-280. http://dx.doi.org/10.1590/S0102 311 X2008000200005

Ronzani TM, Silva CM. Brazil's Family Health program according to healthcare practitioners, managers and users. Cien Saúde Colet. 2008; 13(1):23-34. http://dx.doi.org/10.1590/S1413-81232008000100007

Tanaka OY, Ribeiro EL. Mental health in primary care: Ways to reach an integral care. Cien Saúde Colet. 2009; 14(2):477-486. http://

Caprara A, Lima JWO, Marinho ACP, Calvasina PG, Landim LP, Sommerfeld J. Irregular water supply, household usage and dengue:

89 A bio-social study in the Brazilian Northeast. Cad Saúde Pública. 2009; 25(1):S125-S136. http://dx.doi.org/10.1590/S0102$311 \times 2009001300012$

Lopes CLR, Teles SA, Espírito-Santo MP, Lampe E, Rodrigues FP, Motta-Castro ARC, et al. Prevalence, risk factors and genotypes of hepatitis C virus infection among drug users, Central-Western Brazil. Rev Saúde Pública. 2009; 43(1):43-50. http://dx.doi. org/10.1590/S0034-89102009000800008

Scatena LM, Villa TCS, Netto AR, Kritski AL, Figueiredo TMRM, Vendramini SHF, et al. Difficulties in the accessibility to health services for tuberculosis diagnoses in Brazilian municipalities. Rev Saúde Pública. 2009; 43(3):389-97. http://dx.doi.org/10.1590/ S0034-89102009005000022

Chrestani MAD, Santos IS, Matijasevich AM. Self-reported hypertension: Validation in a representative cross-sectional survey. Cad Saúde Pública. 2009; 25(11):2395-2406. http://dx.doi.org/10.1590/S0102-311X2009001100010

Borges CQ, Silva RCR, Assis AMO, Pinto EJ, Fiaccone RL, Pinheiro SMC. Factors associated with anemia in children and adolescents

93 in public schools in Salvador, Bahia State, Brazil. Cad Saúde Pública. 2009; 25(4):877-888. http://dx.doi.org/10.1590/S0102311 X2009000400019

Santos MS, Hino AAF, Reis RS, Rodriguez-Anez CR. Prevalence of barriers for physical activity in adolescents. Rev Bras Epidemiol. 2010; 13(1):94-104. http://dx.doi.org/10.1590/S1415-790X2010000100009

Lima ALL, Silva ACF, Konno SC, Conde WL, Benicio MHDA, Monteiro CA. Causes of the accelerated decline in child undernutrition in Northeastern Brazil (1986-1996-2006). Rev Saúde Pública. 2010; 44(1):17-27. http://dx.doi.org/10.1590/S003489102010000100002

Ayres ARG, Silva GA. Cervical HPV infection in Brazil: Systematic review. Rev Saúde Pública. 2010; 44(5):963-74. http://dx.doi. org/10.1590/S0034-89102010000500023

Antunes JLF, Narvai PC. Dental health policies in Brazil and their impact on health inequalities. Rev Saúde Pública. 2010; 44(2):3605. http://dx.doi.org/10.1590/S0034-89102010005000002

98 Chor D, Werneck GL, Faerstein E, Alves MGM, Rotenberg L. The Brazilian version of the effort-reward imbalance questionnaire to assess job stress. Cad Saúde Pública. 2008; 24(1):219-224. http://dx.doi.org/10.1590/S0102-311X2008000100022

Monteiro CA, Florindo AA, Claro RM, Moura EC. Validity of indicators of physical activity and sedentariness obtained by telephone survey. Rev Saúde Pública. 2008; 42(4):575-81. http://dx.doi.org/10.1590/S0034-89102008000400001

Barreto SM, Figueiredo RC. Chronic diseases, self-perceived health status and health risk behaviors: Gender differences. Rev Saúde Pública. 2009; 43(2):38-47. http://dx.doi.org/10.1590/S0034-89102009000900006

Pepe VLE, Ventura M, Sant'ana JMB, Figueiredo TA, Souza VR, Simas L, et al. Characterization of lawsuits for the supply of "essential"

101 medicines in the State of Rio de Janeiro, Brazil. Cad Saúde Pública. 2010; 26(3):461-471. http://dx.doi.org/10.1590/S0102$311 \times 2010000300004$

Bezerra IN, Sichieri R. Characteristics and spending on out-of-home eating in Brazil. Rev Saúde Pública. 2010; 44(2):221-9. http:// dx.doi.org/10.1590/S0034-89102010000200001

103 Galduroz JCF, Sanchez ZVDM, Opaleye ES, Noto AR, Fonseca AM, Gomes PLS, et al. Factors associated with heavy alcohol use among students in Brazilian capitals. Rev Saúde Pública. 2010; 44(2):267-73. http://dx.doi.org/10.1590/S0034-89102010000200006

Clemens SAC, Farhat CK. Seroprevalence of herpes simplex 1-2 antibodies in Brazil. Rev Saúde Pública. 2010; 44(4):726-34. http:// dx.doi.org/10.1590/S0034-89102010000400017

Silva AAM, Silva LM, Barbieri MA, Bettiol H, Carvalho LM, Ribeiro VS, et al. The epidemiologic paradox of low birth weight in Brazil. 
Table 2. Characteristics of the most-cited articles in the public health area between 2008 and 2010. $(n=105)$

\begin{tabular}{|c|c|c|}
\hline Characteristics & $\mathbf{n}$ & $\%$ \\
\hline \multicolumn{3}{|l|}{ Publication year } \\
\hline 2008 & 42 & 40 \\
\hline 2009 & 39 & 37 \\
\hline 2010 & 24 & 23 \\
\hline \multicolumn{3}{|l|}{$\#$ authors } \\
\hline 1 & 5 & 5 \\
\hline 2 & 22 & 21 \\
\hline 3 or more & 78 & 74 \\
\hline \multicolumn{3}{|l|}{ Language } \\
\hline Portuguese & 45 & 43 \\
\hline English and Portuguese & 36 & 34 \\
\hline English & 24 & 23 \\
\hline \multicolumn{3}{|l|}{ Area } \\
\hline Epidemiology & 78 & 74 \\
\hline Policies, Planning, and Management & 20 & 19 \\
\hline Social and Human Sciencies in Health & 7 & 7 \\
\hline \multicolumn{3}{|l|}{ Article type } \\
\hline Original & 73 & 70 \\
\hline Methodological & 17 & 16 \\
\hline Review & 15 & 14 \\
\hline \multicolumn{3}{|l|}{ Funding } \\
\hline Yes & 52 & 50 \\
\hline No & 53 & 50 \\
\hline
\end{tabular}

Table 3. Distribution of the most-cited articles by public health journal. $(n=105)$

\begin{tabular}{lcc}
\hline \multirow{2}{*}{ Journal (Institution) } & \multicolumn{2}{c}{ Most-cited articles } \\
\cline { 2 - 3 } Cad Saúde Pública (Fiocruz) & $\mathbf{n}$ & $\%$ \\
\hline Rev Saúde Pública (USP/FSP) & 48 & 46 \\
Ciênc \& Saúde Coletiva (Abrasco) & 39 & 37 \\
Rev Bras Epidemiol (Abrasco) & 12 & 11 \\
Interface (Unesp) & 5 & 1 \\
Hist Ciênc Saúde Manguinhos (Fiocruz) & 1 & 0 \\
Physis (UERJ) & 0 & 0 \\
Saúde e Sociedade (USP/FSP and APSP) & 0 & 0 \\
\hline Total & 0 & $\mathbf{1 0 0}$ \\
\hline
\end{tabular}

Table 4. Institutional affiliation of the first author of $\geq 3$ the most-cited articles published by public health journals edited in Brazil between 2008 and 2010. $(n=105)$

\begin{tabular}{lccc}
\hline Institution & Category & $\mathbf{n}$ & $\%$ \\
\hline Universidade de São Paulo & Public university & 23 & 22 \\
Fiocruz-Fundação Oswaldo Cruz & Governmental institution & 11 & 11 \\
Universidade Federal de Pelotas & Public university & 10 & 10 \\
Ministério da Saúde (Brazil) & Governmental institution & 6 & 6 \\
Universidade Estadual do Rio de Janeiro & Public university & 4 & 4 \\
Universidade Federal da Bahia & Public university & 4 & 4 \\
Universidade Federal de Minas Gerais & Public university & 4 & 4 \\
Universidade Católica de Pelotas & Private university & 4 & 4 \\
Universidade Federal de Santa Catarina & Public university & 3 & 3 \\
Universidade Federal de São Paulo & Public university & 3 & 3 \\
Universidade Federal do Rio Grande do Sul & Public university & 3 & 3 \\
\hline
\end{tabular}


Table 5. Authors who contributed to $\geq 3$ most-cited articles of public health journals edited in Brazil and published between 2008 and 2010, according to authorship, coauthorship and the sum of both.

\begin{tabular}{lcccc}
\hline Author & ResearcherID & Authoring & Coauthoring & Total \\
\hline Monteiro, Carlos Augusto & F-9892-2012 & 3 & 4 & 7 \\
Malta, Deborah Carvalho & H-7880-2012 & 2 & 4 & 6 \\
Barros, Aluísio Jardim Dornellas & A-7417-2008 & 0 & 5 & 5 \\
Barros, Fernando C. & D-4857-2013 & 3 & 1 & 4 \\
Castro, Inês Rugani Ribeiro & - & 1 & 3 & 4 \\
Levy, Renata Bertazzi & F-8931-2012 & 1 & 3 & 4 \\
Claro, Rafael Moreira & F-8996-2012 & 0 & 4 & 4 \\
Hallal, Pedro Curi & A-3249-2011 & 0 & 4 & 4 \\
Horta, Bernardo Lessa & A-7604-2008 & 0 & 4 & 4 \\
Sardinha, Luciana Monteiro Vasconcelos & - & 0 & 4 & 4 \\
Victora, Cesar Gomes & D-4476-2013 & 0 & 4 & 4 \\
Schraiber, Lilia Blima & B-5708-2014 & 2 & 1 & 3 \\
Florindo, Alex Antonio & K-1870-2013 & 1 & 2 & 3 \\
Moura, Erly Catarina & - & 0 & 3 & 3 \\
Moura, Lenildo & - & 0 & 3 & 3 \\
\hline
\end{tabular}

\section{DISCUSSION}

The number of citations received by public health articles differs significantly from that found by studies in diverse subjects and countries, varying from about four thousand citations received $^{5}$ to one thousand ${ }^{18}$, from the medical field, but over an extended period, stretching back to the 1950s. In a bibliometric study of systematic reviews, Royle et al. ${ }^{19}$ found an average of 26.5 citations after four years of publication. The authors used the same information source, the Scopus database, and a similar analysis period (year of 2008) to that of our study. In our study, median citations were equal to 28 . Although we included a period longer than that of Royle et al. ${ }^{19}$, which could overestimate the total citations of the articles of our study compared with the one of Royle et al. ${ }^{19}$, this overestimation would be counterbalanced since systematic reviews tend to receive more citations ${ }^{20,21}$. In fact, the number of citations potentially reflects the process of creation and dissemination, which differs between the areas of knowledge $\mathrm{e}^{22}$, the periods covered and the data sources, among other factors.

Less than $5 \%$ of the most-cited articles have only one author, while most (74\%) have three or more authors. This result corroborates the literature on the positive influence of the number of authors per article on the number of citations received ${ }^{23}$. Regarding language, more than half were published in English (part of them, bilingual). Clearly, it denotes the effort for internationalization by the journals edited in Brazil.

The proportion of the most-cited articles reduced from 2008 to 2010. Certainly, the more recent, the less time the article would be found, read and quoted more often and by more authors. However, for all articles, we counted citations received up to five years after publication, reducing the bias of publication year. Thus, this result may have been due to the number of article journals published during the years considered in this study. In fact, the two journals that contributed the most to the list of the most-cited articles published a total of 605 articles in 2008, 521 in 2009, and 422 in 2010; that is, the number of most-cited articles decreased as the total of articles also decreased.

As for the influence of the impact factor of journals on the citations, there are controversies. According to Callaham et al. ${ }^{24}$, the greater the impact of the journal, the more its articles are cited. The authors reported the impact factor is more influential even than variables related to the quality of the investigation, such as the study design and other methodological aspects. As a matter of fact, the two journals with the highest 
impact factors (SJR 2010 for Cadernos de Saúde Pública $=0.788$ and for Revista de Saúde Pública $=0.817$ ) published $83 \%$ of the most-cited articles between 2008 and 2010. Shadgan et al. ${ }^{18}$, when evaluating the most-cited articles in the medical field, also found most of these were published by journals with a high impact factor. For Larivière and Gingras $^{25}$, this influence can result both from the better dissemination of the journals that have a greater impact, and from the citing researchers' perception that the articles published in these journals have higher quality.

Slyder et al. ${ }^{2}$, however, emphasize that being published by high impact journals does not guarantee that the article is highly cited since the citation rate varies greatly between articles. This indicates that other features in these articles make them attract more citations. The study by Royle et al..$^{19}$ corroborates this information by showing that, although impact metrics have explained more than half of the variation in citations, they do not accurately represent the number of citations of individual articles.

It should be noted that, when analyzing the journals in which the most-cited articles were published, a consistency can be seen between the order of the most-cited articles and the number of those that did not receive any citations ${ }^{17}$, i.e., the journals that published more articles with the highest number of citations were also the ones that published fewer articles that have never been cited.

Regarding the sub-areas, Iriart et al. ${ }^{10}$, in a recent evaluation of the scientific production of postgraduate programs in the public health area, found a similar tendency in the proportion of researchers in each discipline: $49 \%$ belong to Epidemiology; 20\%, to Health Policies, Planning and Management; and 17\%, to the Social and Human Sciences in Health. This proportion is reflected, in this study, by the distribution of the most-cited articles according to the sub-areas.

The search for institutional excellence has aroused interest in identifying the institutions performing best in the development of science in a country, or in a specific area. In public health in Brazil, public universities stand out as science generators. Packer and Meneghini ${ }^{12}$, in 2006, had already identified the influence of public universities on the impact of articles. Both in this paper and in the study by Packer and Meneghini ${ }^{12}$, the presence of private higher education institutions in the most-cited articles was also observed, although to a lesser extent.

In Brazil, public health research is subsidized by development agencies, national government agencies and mainly by public resources ${ }^{26,27}$, as corroborated by our study. We can infer that this is a characteristic of developing countries, such as Brazil, and of a multidisciplinary area, such as public health, while private financing is correlated with the highest citation index in the area of cardiology in developed countries ${ }^{28}$. However, some journals do not adopt the requirement of funding acknowledgments, and this fact may have led to the large proportion of articles classified as being without financial support $\mathrm{t}^{27}$.

As for the type of article among the most-cited, we selected a priori the categories original articles and reviews to ensure research articles, supposing that editorials, opinions, comments, among others are not expected to receive enough citations to be among the most-cited publications. In this study, we found an opinion article among the most-cited, besides debates, forums, and notes, which were then categorized by the authors according to the classifications considered in this investigation (original, methodological, or review). This is an error that can be attributed to the indexer or editor of the journal. This is a limitation of our study, since other records not indexed as original articles or reviews may have had more citations than the 105 articles included here.

Another limitation is that we used only the Scopus database in data collection. However, this is the database that indexes most journals of public health edited in Brazil, which is why it was chosen. Also, our findings are limited by the fact that we have not assessed the quality of the citations. 
Additionally, we emphasize that the object of this study was the scientific journals edited in Brazil and their respective articles. As the literature on public health tends to be dispersed in journals from other areas (Medicine, Psychology, Oral Health, etc.), our findings are limited to a part of the Brazilian scientific production. Future investigation evaluating public health articles published by journals from other areas of knowledge may provide a broader picture of the scientific production in this area.

\section{CONCLUSION}

This panorama of the most-cited articles in the field of public health helps us to understand the science produced in Brazil in this field of knowledge. The most frequently cited articles are written by groups of authors and researchers affiliated to public institutions, belong to the Epidemiology sub-area, and are published in journals that have a greater impact. This may inspire new generations of scientists as to the characteristics that will potentially increase the impact of their research. Periodical analyses such as these can show possible changes in the characteristics of articles that most attract public health scientists. Future investigation assessing the citing articles of public health journals could clarify the quality of the citations. Also, future studies evaluating public health articles published by journals from other areas of knowledge may provide a broader picture of the scientific production in this area.

\section{REFERENCES}

1. Hamilton DP. Publishing by-- and for? -- the Numbers: new evidence raises the possibility that a majority of scientific papers make negligible contributions to knowledge. Science.1990;250(4986):1331-2. https://doi.org/10.1126/Science.2255902

2. Slyder JB, Stein BR, Sams BS, Walker DM, Bealey BJ, Feldhaus JJ, et al. Citation pattern and lifespan: a comparison of discipline, institution, and individual. Scientometrics. 2011;89:955. https://doi.org/10.1007/s11192-011-0467-x

3. Garfield E, Welljams-Dorof A. Of noble class: a citation perspective on high impact research authors. Theor Med. 1992;13(2):117-35.

4. Perez-Cabezas V, Ruiz-Molinero C, Carmona-Barrientos I, Herrera-Viedma E, Cobo MJ, Moral-Munoz JA. Highly cited papers in rheumatology: identification and conceptual analysis. Scientometrics. 2018;116(1):555-68. https://doi.org/10.1007/s11192-018-2712-z

5. Tang X, Gong W, Yuan F, Li R, Han X, Huang S, et al. Top-cited articles in digestive system disease from 1950 to 2013. J Gastroenterol Hepatol. 2016;31(1):107-11. https://doi.org/10.1111/jgh.13032

6. Mazhari S. The 100 top-cited articles published in psychiatry journals. J Psychiatr Pract. 2013;19(4):327-38. https://doi.org/10.1097/01.pra.0000432604.06835.da

7. Bayley M, Brooks F, Tong A, Hariharan K. The 100 most cited papers in foot and ankle surgery. Foot (Edinb). 2014;24(1):11-6. https://doi.org/10.1016/j.foot.2013.11.003

8. Ranasinghe I, Shojaee A, Bikdeli B, Gupta A, Chen R, Ross JS, et al. Poorly cited articles in peer-reviewed cardiovascular journals from 1997 to 2007: analysis of 5-year citation rates. Circulation. 2015;131(20):1755-62. https://doi.org/10.1161/CIRCULATIONAHA.114.015080

9. Alvarenga AT, Sommerman A, Alvarez AMS. Congressos internacionais sobre transdisciplinaridade: reflexões sobre emergências e convergências de ideias e ideais na direção de uma nova ciência moderna. Saude Soc. 2005;14(3):9-29. https://doi.org/10.1590/S0104-12902005000300003

10. Iriart JAB, Deslandes SF, Martin D, Carmargo Jr KR, Carvalho MS, Coeli CM. A avaliação da produção científica nas subáreas da Saúde Coletiva: limites do atual modelo e contribuições para o debate. Cad Saude Publica. 2015;31(10):2137-47. https://doi.org/10.1590/0102-311X00065515

11. Smith DR, Leggat PA. Ten citation classics from the Australian and New Zealand Journal of Public Health. Aust N Z J Public Health. 2008;32(2):105-6. https://doi.org/10.1111/j.1753-6405.2008.00183.x 
12. Packer AL, Meneghini R. Articles with authors affliliated to Brazilian institutions published from 1994 to 2003 with 100 or more citations: I The weight of international collaboration and the role of the networks. An Acad Bras Cienc. 2006;78(4):841-53. https://doi.org/10.1590/S0001-37652006000400017

13. Leta J. Brazilian growth in the mainstream science: the role of human resources and national journals. J Scientometric Res.2012;1(1):44-52. https://doi.org/10.5530/jscires.2012.1.9

14. Mugnaini R, Digiampetri LA, Mena-Chalco JP. Comunicação científica no Brasil (1998-2012): indexação, crescimento, fluxo e dispersão. Transinformação. 2014;26(3):239-52. https://doi.org/10.1590/0103-3786201400030002

15. Coimbra Jr CEA. Produção científica e impacto em Saúde Coletiva. Cad Saude Publica. 2004;20(4):878-9. https://doi.org/10.1590/S0102-311X2004000400001

16. Barata RB. SciELO Saúde Pública: o desempenho dos Cadernos de Saúde Pública e da Revista de Saúde Pública. Cad Saude Publica. 2007;23(12):3031-40. https://doi.org/10.1590/S0102-311X2007001200025

17. Cuenca AMB, Barbosa MMAL, Oliveira K, Quinta FP, Alvarez MCA, França Jr I. Artigos não citados nas revistas brasileiras em Saúde Pública. Rev Saude Publica. 2017;51:114. http://dx.doi.org/10.11606/s1518-8787.2017051000442

18. Shadgan B, Roig M, HajGhambari B, Reid WD. Top-cited articles in rehabilitation. Arch Phys Med Rehabil. 2010;91(5):806-15. https://doi.org/10.1016/j.apmr.2010.01.011

19. Royle P, Kandala NB, Barnard K, Waugh N. Bibliometrics of systematic reviews: analysis of citation rates and journal impact factors. Systematic Rev. 2013;2:74. https://doi.org/10.1186/2046-4053-2-74

20. Patsopoulos NA, Analatos AA, loannidis JPA. Relative citation impact of various study designs in the Health Sciences. JAMA. 2005;293(19):2362-6. https://doi.org/10.1001/jama.293.19.2362

21. Bhandari M, Busse J, Devereaux PJ, Montori VM, Swiontkowski M, Tornetta P, III, et al. Factors associated with citation rates in the orthopedic literature. Can J Surg. 2007 [cited 2017 Febr 15];50(2):119-23. Available from: https://www.ncbi.nlm.nih.gov/pmc/articles/PMC2384258/

22. Pendlebury DA. Science, citation and funding [letter to the editor]. Science. 1991 [cited 2017 Febr 15];251:1410-1. Available from: http://garfield.library.upenn.edu/papers/ pendleburyscience1991.html

23. Figg WD, Dunn L, Liewehr DJ, Steinberg SM, Thurman PW, Barrett JC, et al. Scientific collaboration results in higher citations rates of published articles. Pharmacotherapy. 2006;26(6):759-67. https://doi.org/10.1592/phco.26.6.759

24. Callaham M, Wears RL, Webwe E. Journal prestige, publication bias, and other characteristics associated with citation of published studies in peer-reviewed journals. JAMA. 2002;287(21):2847-50. https://doi.org/10.1001/jama.287.21.2847

25. Larivière $V$, Gingras $Y$. The impact factor's Matthew effect: a natural experiment in Bibliometrics. J Am Soc Inf Sci Technol. 2010;61(2):424-7. https://doi.org/10.1002/asi.21232

26. Guimarães R. Pesquisa em saúde no Brasil: contexto e desafios. Rev Saude Publica. 2006; $40 \mathrm{n}^{\circ}$ espec:3-10. https://doi.org/10.1590/S0034-8910200600040000

27. Cuenca AMB, Noronha DP, Ueno HM, Kobayashi KM. Periódicos brasileiros de saúde pública: a questão do financiamento. INCID Rev Cienc Inf Doc. 2011;2(2):101-10. https://doi.org/10.11606/issn.2178-2075.v2i2p101-110

28. Khan MS, Usman MS, Fatima K, Hashmani N, Siddiqi TJ, Riaz H, et al. Characteristics of highly cited articles in interventional cardiology. Am J Cardiol. 2017;120(11):2100-9. https://doi.org/10.1016/ j.amjcard.2017.08.030

Funding: Universidade de São Paulo (Programa Institucional de Bolsas de Iniciação Científica - scholarship to KO; Programa Unificado de Bolsas - scholarship to LYO).

Authors' Contributions: Conception of the work: MMALB, AMBC; acquisition, analysis, and interpretation of data for the study: MMALB, KO, AMBC, IFJ, MCAA, LYO; drafting the study and revising it critically for important intellectual content: MMALB, AMBC, IFJ; final approval of the version to be published: MMALB, KO, AMBC, IFJ, MCAA, LYO; agreement to be accountable for all aspects of the study in ensuring that questions related to the accuracy or integrity of any part of the study are appropriately investigated and resolved: MMALB, KO, AMBC, IFJ, MCAA, LYO.

Acknowlegments: To Fernanda Paranhos Quinta, for the contribution to data collection.

Conflict of Interest: The authors declare no conflict of interest. 